\title{
Evaluation of Guidelines for Developing Digital Leadership of School Administrators According to the School Development Model Towards Leadership in Digital Era
}

\author{
Kanyarat Suksaen ${ }^{1}$, Pratoomtong Trirat ${ }^{2}$, Sakda Sakonthawat ${ }^{3}$, Artip Sornsujitra ${ }^{4}$ \\ ${ }^{1}$ Pawiittra School, ${ }^{2}$ Suriyadhep Teachers College, Rangsit University, \\ ${ }^{3}$ ACP, Thailand, ${ }^{4}$ St.Gabriel's Foundation, Thailand
}

\begin{abstract}
This research was aimed to 1) determine the current and desirable states, and the priority needs index of the guidelines for developing digital leadership of school administrators according to the school development model towards leadership in digital era; 2) evaluate the guidelines for developing digital leadership of school administrators. Mixed methods research was employed and undertaken in 2 phrases. Phrase 1 investigated the model. The sample includes 14 schools affiliated to the Saint Gabriel's Foundation, Thailand in 2020 academic year. Instruments consist of concept questionnaire, current and desirable states questionnaire, model propriety and feasibility evaluation form. Phrase 2 evaluated the model's guidelines for developing digital leadership of school administrators according to the school development model towards leadership in digital era by means of interviews with 30 experts of human resource development, digital technology, and education administration. Instruments comprise structured questionnaire, and guidelines propriety and feasibility evaluation form. Analyses involve descriptive statistics i.e. frequency, percentage, mean, and standard deviation, PNI Modified, and content analysis.

Results of evaluation of the guidelines for developing digital leadership of school administrators according to the school development model towards leadership in digital era revealed that the current and desirable states are in overall at a moderate and highest level, respectively. The highest values of priority needs index of the guidelines in different elements are as follows: transformation ranked first for the development goals; engagement ranked first for the development methods; building capacity for rapid operation ranked first for the development objectives; and digital knowledge and skills development and organizational management ranked first for the self-assessment process.
\end{abstract}

\section{Keywords}

Digital leadership development, Digital leadership, School administrators

Index Terms - PPICC: Purpose and Processing on Ideation and Creative Innovations for Competency Model, Creative Innovations, Competency Innovator

\section{Article Received: 10 August 2020, Revised: 25 October 2020, Accepted: 18 November 2020}

\section{Introduction}

Digital technology has been developed and used in daily life and at work. Many organizations have utilized information technology to assist their operation. Information technology has also been increasingly used in educational management. According to G.N. Wikramanayake (2005) in a research on the impact of digital technology on education, traditionally education is centered on sources such as schools, teachers and print media. The learners reached the information sources by enrolling with schools, teachers and libraries. Prior to the digital era, information was not accessible by the majority of people, and even those accessed were unable to obtain current information with respect to today's context. The modern society wants to know the information as it happens and when it happens, and the world is moving from an information society to a knowledge society. Thus education is given the highest priority and brainpower is becoming the most valuable asset of an organization. Advances in digital technology have opened up many avenues of learning. Technology has made information accessible / transmittable from anywhere and by / to all groups of people. Education has reached most parts of the world and ICT has become an integral part of human life. It is in line with Ananiadou, Katerina Claro, Magdalean (2009) discussing about issues related to the teaching and assessment of 21 st century skills and competences for new millennium learners in OECD countries. The survey findings show most countries or regions cover 21 st century skills and competencies in their guidelines for compulsory education however with few specific 
definitions of these skills and competencies and no clear formative or summative assessment policies for these skills. The only evaluation regarding their teaching is often left to external inspectors as part of their whole school audits. Similarly, there are few teacher training programs that target the teaching or development of $21 \mathrm{st}$ century skills. Although there exist several teacher training initiatives that focus on developing teachers' ICT pedagogical skills, most of them are optional. As school administrators are required to provide guidelines for developing teachers who are school staff, they need to be knowledgeable about and perform the role in motivating and following-up for the development to be more efficient and keep pace with changes in digital technology.

Technological changes and transformation of communication that link to the digital age allow for an organization to step toward the success and attainment of goals. Thus, human resource development is particularly important. If organizations want to keep pace with and be ahead of the competition, they need to develop their personnel at all levels, more importantly in terms of leadership, keeping up with changes and using techniques and tools to manage efficiently at work. In similar, school administrators have to adjust their management to be ready to engage in the international world, to keep up with changes, and to use information technology in communication and management as well as in educational management. This is to ensure that the organization can adapt and develop to follow the changes and reduce risks or impacts that will occur. Administrator as organization leader need to be developed and equipped with knowledge, competencies and skills essential for leader who can evolve and keep pace with the rapid and continuous change of digital technology and can also use it safely, creatively, and ethically. Excellent leaders are required for an organization to be active, sustain its growth, be more efficient than competitors, and retain the share and distinctive performance. Leadership development of school administrators will enable their management of instruction, resources, student affairs, and building cooperation and network that will lead to school development in accordance with the standards. In this research, results of the model will be valuable to quality improvement of education provision and effect students which is in line with educational reform policy. It will also serve as guidelines for school management for its quality and benefit to educational development.

\section{Objectives}

1. To determine the current and desirable states, and the propriety needs index of the guidelines for developing digital leadership of school administrators according to the school development model towards leadership in digital era;

2. To evaluate the guidelines for developing digital leadership of school administrators according to the school development model towards leadership in digital era;

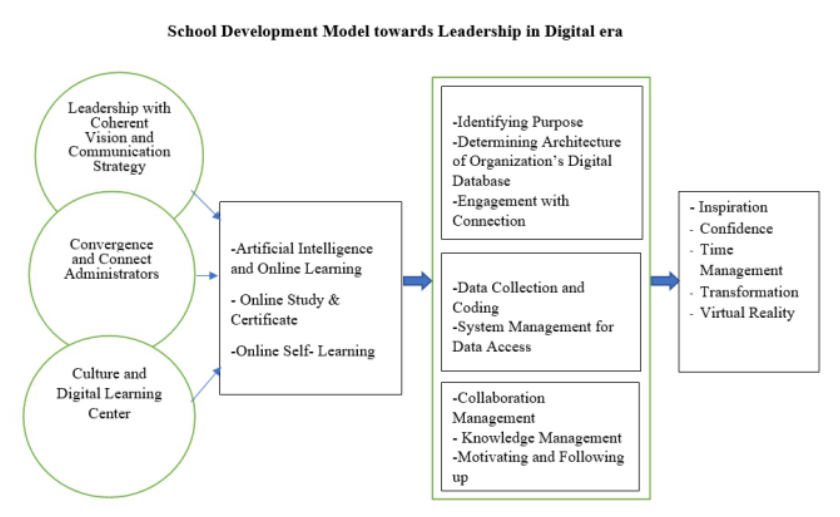

\section{Research Methodology}

This research employed a mixed methods approach. The population consists of schools affiliated to the St. Gabriel's Foundation, Thailand. The research sample for Phrase 1 includes 14 private schools affiliated to the St. Gabriel's Foundation, Thailand. There are 2 groups of informants: group 1 comprises administrators of the 14 schools including school directors, deputy directors, and chiefs in charge of administration at different levels; group 2 comprises teachers in charge of school human resource of the 14 schools.

For the research method and instrument, a mixed methods approach was utilized and undertaken in 2 phrases with 3 steps as follows.

Phrase 1: Step 1 involves the review of documents regarding the concepts, theories, and research works related to digital leadership development so as to guide the determination of guidelines for developing digital leadership of private school administrators affiliated to the St Gabriel's 
Foundation, Thailand according to the school development model towards leadership in digital era. The digital leadership development model was constructed based on the future trends in leadership development by Nick Petrie (Personnel Development Process, 2011); PREPARE Framework for Leadership development by D. Scott DeRue and Christopher G. Myers; Human Resource Development in Digital Age (Techsauce Team, 2018); digital leadership model and the composition of digital leadership from a study on digital leadership by Elliott (2017), ISTE Standards for Education Leaders: iste.org/standards 2019; and the success oriented digital leadership development model by Pakorn Leesakul (2018). The analysis of concepts and theories of these scholars suggest that the leadership development model involves developing and investigating the current and desirable states; determining priority needs index; and constructing, evaluating and presenting the model.

\section{Phrase 2}

Step 1: Bringing the school development model towards leadership in digital era to perform interviews with 30 experts, and drawing conclusions.

Step 2: Determining the current and desirable states and the priority needs index of the guidelines for developing digital leadership of school administrators according to the school development model towards leadership in digital era.

\section{Research Findings}

The current and desirable states and the priority needs index of the guidelines for developing digital leadership of school administrators according to the school development model towards leadership in digital era are presented in Tables $1-3$ as follows.

Table 1 Current and desirable states and the priority needs index of the guidelines for developing digital leadership of school administrators according to the goals of school development model towards leadership in digital era, in overall

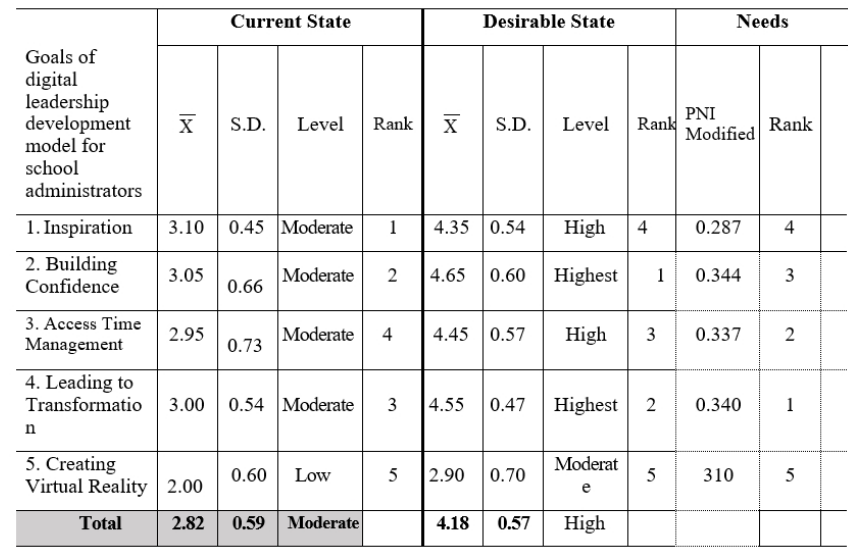

Table 1 shows that the current state of the guidelines for developing digital leadership of school administrators according to the goals of school development model towards leadership in digital era is at a moderate level in overall and ranked by elements with top three values as inspiration, confidence, and transformation, respectively. The desirable state of the guidelines is at a high level in overall and ranked respectively by confidence, transformation, and time management. The values of priority needs index are ranked respectively as transformation, time management, and confidence.

Table 2 Current and desirable states, and priority needs index of the elements of digital leadership development of school administrators by the development method according to the elements of school development model, in overall

\begin{tabular}{|c|c|c|c|c|c|c|c|c|c|c|}
\hline \multirow{2}{*}{$\begin{array}{l}\text { Method of digital } \\
\text { leadership } \\
\text { development based } \\
\text { on the digital } \\
\text { leadership } \\
\text { development model } \\
\text { for school } \\
\text { administrators }\end{array}$} & \multicolumn{4}{|c|}{ Current State } & \multicolumn{4}{|c|}{ Desirable State } & \multicolumn{2}{|c|}{ Needs } \\
\hline & $\overline{\mathrm{x}}$ & S.D. & Level & $\begin{array}{c}\text { Ran } \\
\mathrm{k}\end{array}$ & $\overline{\mathrm{x}}$ & $\frac{\underline{s}}{\underline{D}}$ & Level & Rank & $\begin{array}{l}\text { PNI } \\
\text { Modified }\end{array}$ & Rank \\
\hline $\begin{array}{l}\text { Methods of } \\
\text { development by } \\
\text { main elements and } \\
\text { sub elements }\end{array}$ & & & & & & & & & & \\
\hline $\begin{array}{l}\text { 1. Leadership with } \\
\text { Coherent Vision } \\
\text { and Communication } \\
\text { Strategy }\end{array}$ & 3.33 & 0.46 & Moderate & 1 & 4.51 & $1 \quad 0.52$ & Highest & 3 & 0.262 & 3 \\
\hline $\begin{array}{l}1.1 \text { Identifying } \\
\text { Purpose }\end{array}$ & 3.35 & 0.47 & \begin{tabular}{|l} 
Moderate \\
\end{tabular} & 2 & 4.35 & $\begin{array}{ll}5 & 0.47\end{array}$ & High & 3 & 0.229 & 3 \\
\hline $\begin{array}{l}1.2 \text { Determining } \\
\text { Architecture of } \\
\text { Organization's } \\
\text { digital database }\end{array}$ & 3.25 & 0.45 & Moderate & 3 & 4.50 & 0.56 & High & 2 & 0.277 & 1 \\
\hline $\begin{array}{l}1.3 \text { Engagement } \\
\text { with connection }\end{array}$ & 3.40 & 0.48 & \begin{tabular}{|l|} 
Moderate \\
\end{tabular} & 1 & 4.70 & 0.55 & Highest & 1 & 0.276 & 2 \\
\hline $\begin{array}{l}\text { 2. Engagement with } \\
\text { Connection }\end{array}$ & 3.12 & 0.55 & Moderate & 3 & 4.62 & 0.50 & Highest & 2 & 0.324 & 1 \\
\hline $\begin{array}{l}2.1 \text { Convergence } \\
\text { and Connect } \\
\text { Admininistration }\end{array}$ & 3.30 & 0.55 & Moderate & 1 & 4.55 & 0.45 & Highest & 2 & 0.274 & 2 \\
\hline $\begin{array}{l}2.2 \text { System } \\
\text { Management }\end{array}$ & 2.95 & 0.56 & Moderate & 2 & 4.70 & 0.55 & Highest & 1 & 0.372 & 1 \\
\hline $\begin{array}{l}\text { 3. Culture and } \\
\text { Digital Learning } \\
\text { Center }\end{array}$ & 3.28 & $\begin{array}{c}0.47 \\
3\end{array}$ & Moderate & 2 & 4.66 & 0.55 & Highest & 1 & 0.297 & 2 \\
\hline $\begin{array}{l}3.1 \text { Collahoration } \\
\text { Manangegement }\end{array}$ & 3.35 & $\mid 0.47$ & Moderate & 1 & 4.60 & 0.56 & Highest & 2 & 0.271 & 2 \\
\hline $\begin{array}{l}3.2 \text { Knowledge } \\
\text { Management }\end{array}$ & 3.30 & 0.55 & Moderate & 2 & 4.50 & 0.60 & High & 3 & 0.266 & 3 \\
\hline $\begin{array}{l}\text { 3.3 Motivating and } \\
\text { Following up }\end{array}$ & 3.20 & 0.40 & Moderate & 3 & 4.90 & 0.50 & Highest & 1 & 0.346 & 1 \\
\hline Total & 3.24 & & Moderate & & 4.49 & & Highest & & & \\
\hline
\end{tabular}


Table 2 shows that the current state of guidelines for developing digital leadership of school administrators according to the school development model towards leadership in digital era in the element of development method is at a moderate level in overall, and ranked respectively by values as coherent vision and communication strategy; culture and digital learning center; and engagement. The desirable state is at a highest level in overall, and ranked respectively by values as culture and digital learning center; engagement; and coherent vision and communication strategy. The values of priority needs index are ranked respectively as engagement; culture and digital learning center; and engagement.

Table 3 Current and desirable states, and priority needs index of elements of digital leadership development of school administrators by the development objectives according to the elements of school development model, in overall

\begin{tabular}{|c|c|c|c|c|c|c|c|c|c|c|}
\hline \multirow[b]{2}{*}{$\begin{array}{l}\text { Objectives of } \\
\text { Leadership } \\
\text { Development }\end{array}$} & \multicolumn{4}{|c|}{ Current State } & \multicolumn{4}{|c|}{ Desirable State } & \multicolumn{2}{|c|}{ Needs } \\
\hline & $\overline{\mathrm{x}}$ & S.D. & Rank & Level & $\overline{\mathrm{x}}$ & S.D. & Rank & Level & \begin{tabular}{c|} 
PNI \\
Modified
\end{tabular} & Rank \\
\hline $\begin{array}{l}\text { 1. Making dynamic } \\
\text { decision in } \\
\text { connection with the } \\
\text { main purpose } \\
\text { according to the } \\
\text { strategy toward the } \\
\text { goal of value of } \\
\text { service and product } \\
\text { (North Star Metric) }\end{array}$ & 3.40 & 0.64 & 1 & Moderate & 4.70 & 0.47 & 5 & Highest & 0.276 & 4 \\
\hline $\begin{array}{l}\text {. Elevating the } \\
\text { organization for } \\
\text { creativity and } \\
\text { highest efficiency }\end{array}$ & 3.35 & 0.70 & 2 & Low & 4.75 & 0.44 & 4 & Highest & 0.294 & 5 \\
\hline $\begin{array}{l}\text { 3. Building up } \\
\text { capability of rapid } \\
\text { operation }\end{array}$ & 3.20 & 0.62 & 5 & Moderate & 4.78 & 0.44 & 2 & Highest & 0.330 & 1 \\
\hline $\begin{array}{l}\text { 4. Establishing a } \\
\text { learning culture }\end{array}$ & 3.30 & 0.63 & 3 & Moderate & 4.77 & 0.46 & 3 & Highest & 0.312 & 3 \\
\hline $\begin{array}{l}\text { 5. Promoting } \\
\text { digital literacy for } \\
\text { effective } \\
\text { leadership }\end{array}$ & 3.25 & 0.59 & 4 & Moderate & 4.85 & 0.43 & 1 & Highest & 0.329 & 2 \\
\hline Total & 3.30 & 0.63 & & Moderate & 4.77 & 0.44 & & Highest & & \\
\hline
\end{tabular}

In Table 3, the current state of elements of digital leadership development of school administrators by the development objectives according to the elements of school development model is at a moderate level in overall. The desirable state is at a highest level in overall. The values of priority needs index are ranked respectively as building up capability of rapid operation; promoting digital literacy for effective leadership; and establishing a learning culture.

Table 4 Current and desirable states, and priority needs index of elements of digital leadership development of school administrators by selfassessment process on digital leadership competency according to the elements of school development model, in overall

\begin{tabular}{|c|c|c|c|c|c|c|c|c|c|c|}
\hline \multirow{2}{*}{$\begin{array}{l}\text { Self-Assessment } \\
\text { Process on Digital } \\
\text { Leadership } \\
\text { Competency }\end{array}$} & \multicolumn{4}{|c|}{ Current State } & \multicolumn{4}{|c|}{ Desirable State } & \multicolumn{2}{|c|}{ Needs } \\
\hline & $\overline{\mathrm{x}}$ & S.D. & Level & Rank & $\overline{\mathrm{x}}$ & S.D. & Level & Rank & $\begin{array}{l}\text { PNI } \\
\text { Modified }\end{array}$ & Rank \\
\hline $\begin{array}{l}\text { 1. Assessment of } \\
\text { digital competency of } \\
\text { administrators }\end{array}$ & & & & & & & & & & \\
\hline $\begin{array}{l}\text { Methods of learning } \\
\text { development by } \\
\text { online self- learning }\end{array}$ & 3.30 & 0.45 & Moderate & & 4.55 & 0.56 & Highest & & 0.274 & \\
\hline $\begin{array}{l}\text { Self-assessment } \\
\text { should include the } \\
\text { essential content and } \\
\text { skills that cover } \\
\text { digital leadership } \\
\text { skills (Lindsay } \\
\text { Sullivan Jum 20, } \\
\text { 2017) }\end{array}$ & 3.53 & & High & & 4.58 & & Highest & & 0.230 & \\
\hline 1.1 Digital literacy & 3.55 & 0.56 & High & 5 & 4.65 & 0.78 & Highest & 3 & 0.236 & 4 \\
\hline 1.2 Digital vision & 3.25 & 0.57 & Moderate & 7 & 4.35 & 0.55 & High & 8 & 0.252 & 2 \\
\hline 1.3 Advocacy & 3.65 & 0.67 & High & 2 & 4.56 & 0.67 & Highest & 4 & 0.199 & 7 \\
\hline 1.4 Presence & 3.45 & 0.75 & High & & 4.50 & 0.56 & High & 5 & 0.233 & 5 \\
\hline 1.5 Communication & 3.75 & 0.67 & High & 1 & 5.00 & 0.00 & Highest & 1 & 0.250 & 3 \\
\hline 1.6 Adaptability & 3.56 & 0.70 & High & 4 & 4.78 & 0.35 & Highest & 2 & 0.255 & 1 \\
\hline 1.7 Self-awareness & 3.59 & 0.45 & High & 3 & 4.45 & 0.58 & High & 7 & 0.193 & 8 \\
\hline $\begin{array}{l}1.8 \text { Cultural } \\
\text { awareness }\end{array}$ & 3.45 & 0.65 & Moderate & 6 & 4.48 & 0.45 & High & 6 & 0.229 & 6 \\
\hline $\begin{array}{l}\text { 1. Methods of digital } \\
\text { knowledge and } \\
\text { skills development } \\
\text { and organizational } \\
\text { management }\end{array}$ & 3.04 & & Moderate & & 4.31 & & High & & 0.296 & \\
\hline $\begin{array}{l}1.1 \text { Artificial } \\
\text { intelligence and } \\
\text { online learning }\end{array}$ & 2.56 & 0.55 & Moderate & 3 & 4.00 & 0.35 & High & 3 & 0.360 & 1 \\
\hline $\begin{array}{l}1.2 \text { Online study \& } \\
\text { certificate }\end{array}$ & 3.34 & 0.65 & Moderate & 1 & 4.45 & 0.56 & High & 2 & 0.246 & 3 \\
\hline $\begin{array}{l}1.3 \text { Online self- } \\
\text { learning center }\end{array}$ & 3.30 & 0.34 & Moderate & 2 & 4.50 & 0.56 & High & 1 & 0.266 & 2 \\
\hline
\end{tabular}

\begin{tabular}{|c|c|c|c|c|c|c|c|c|c|c|}
\hline $\begin{array}{l}\text { 2. Content of the } \\
\text { development } \\
\text { toward digital } \\
\text { leadership }\end{array}$ & 3.26 & & Moderate & & 4.46 & & High & & 0.270 & \\
\hline $\begin{array}{l}\text { Module l: Digital } \\
\text { Transformation } \\
\text { Solutions }\end{array}$ & 3.25 & 2 & Moderate & & 4.45 & & High & 3 & 0.269 & 3 \\
\hline $\begin{array}{l}1.1 \text { Drive key digital } \\
\text { transformation } \\
\text { priorities }\end{array}$ & 3.30 & 0.65 & Moderate & & 4.50 & 0.58 & High & 1 & 0.266 & 3 \\
\hline $\begin{array}{l}1.2 \text { Set driving forces } \\
\text { and key technologies } \\
\text { that enable digital } \\
\text { transformation }\end{array}$ & 3.20 & 0.78 & Moderate & & 4.35 & 0.79 & High & 3 & 0.264 & 4 \\
\hline $\begin{array}{l}1.3 \text { Address your } \\
\text { unique challengess and } \\
\text { optimize digital } \\
\text { transformation ROI } \\
\text { (Return on Investment) }\end{array}$ & 3.25 & 0.76 & Moderate & & 4.45 & 0.56 & High & 2 & 0.269 & 1 \\
\hline $\begin{array}{l}1.4 \text { Copyright and } \\
\text { Digitization }\end{array}$ & 3.29 & 0.56 & Moderate & & 4.50 & 0.46 & High & 1 & 0.268 & 2 \\
\hline $\begin{array}{l}\text { Module 2: Cyber } \\
\text { Security for Network }\end{array}$ & 3.24 & 3 & Moderate & & 4.48 & & High & 2 & 0.278 & 2 \\
\hline $\begin{array}{l}2.1 \text { Identify the risks } \\
\text { and potential impact } \\
\text { of a security attack on } \\
\text { your operational } \\
\text { network }\end{array}$ & 3.23 & 0.54 & Moderate & 3 & 4.55 & 0.58 & Highest & 2 & 0.290 & 1 \\
\hline $\begin{array}{l}2.2 \text { Consider the end- } \\
\text { to-end security of } \\
\text { your critical } \\
\text { infrastructure and } \\
\text { systems }\end{array}$ & 3.25 & 0.76 & Moderate & 2 & 4.35 & 0.76 & High & 3 & 0.252 & 3 \\
\hline $\begin{array}{l}2.3 \text { Utilize our easy } \\
\text { to follow cyber } \\
\text { security checklist to } \\
\text { better protect your } \\
\text { business }\end{array}$ & 3.26 & 0.56 & Moderate & 1 & 4.56 & 0.54 & Highest & 1 & 0.285 & 2 \\
\hline $\begin{array}{l}\text { Module 3: Big Data } \\
\text { for School Work }\end{array}$ & 3.30 & 1 & Moderate & & 4.41 & & High & 4 & 0.252 & 4 \\
\hline $\begin{array}{l}3.1 \text { Analytical } \\
\text { approaches }\end{array}$ & 3.20 & 0.79 & Moderate & 3 & 4.50 & 0.78 & High & 2 & 0.288 & 2 \\
\hline $\begin{array}{l}\text { 3.2Data-driven } \\
\text { analytics approach }\end{array}$ & 3.25 & 0.578 & Moderate & 2 & 4.35 & 0.87 & High & 3 & 0.252 & 3 \\
\hline $\begin{array}{l}3.3 \text { Context- or need- } \\
\text { driven analytics } \\
\text { approach }\end{array}$ & 3.20 & 0.56 & Moderate & 3 & 4.25 & 0.56 & High & 4 & 0.247 & 4 \\
\hline
\end{tabular}




\begin{tabular}{|c|c|c|c|c|c|c|c|c|c|c|}
\hline 3.4 Learning analytics & 3.56 & 0.55 & High & 1 & 4.56 & 0.78 & Highest & 1 & 0.291 & 1 \\
\hline $\begin{array}{l}\text { Module 4: Digital } \\
\text { Literacy for Teacher } \\
\text { Leadership }\end{array}$ & 3.30 & 1 & Moderate & & 4.73 & & Highest & 1 & 0.302 & 1 \\
\hline $\begin{array}{l}1 \text { Find, evaluate, } \\
\text { utilize, share and } \\
\text { create content using } \\
\text { information } \\
\text { technologies and the } \\
\text { internet }\end{array}$ & 3.25 & 0.56 & Moderate & 2 & 4.78 & 0.76 & Highest & 1 & 0.320 & 1 \\
\hline $\begin{array}{l}4.2 \text { Cognitive, critical, } \\
\text { creative and social } \\
\text { skills in digital } \\
\text { technology }\end{array}$ & 3.35 & 0.67 & Moderate & 1 & 4.68 & 0.56 & Highest & 2 & 0.280 & 2 \\
\hline $\begin{array}{l}\text { Module 5: Digital } \\
\text { Disruption }\end{array}$ & 3.22 & 4 & Moderate & & 4.27 & & High & 5 & 0.247 & 5 \\
\hline $\begin{array}{l}5.1 \text { Reframe your } \\
\text { perspective and adopt } \\
\text { proven digital leader } \\
\text { traits }\end{array}$ & 3.25 & 0.56 & Moderate & 1 & 4.25 & 0.76 & High & 2 & 0.235 & 2 \\
\hline $\begin{array}{l}5.2 \text { Reinforce digital } \\
\text { acuity mindset with } \\
\text { daily routines and } \\
\text { rituals }\end{array}$ & 3.20 & 0.78 & Moderate & 2 & 4.30 & 0.87 & High & 1 & 0.255 & 1 \\
\hline
\end{tabular}

In Table 4, the current state of elements of digital leadership development of school administrators by self-assessment process on digital leadership competency according to the elements of school development model suggests that self-assessment to include the essential content and skills that cover digital leadership skills is at a high level in overall. The desirable state is at a highest level in overall, with PNI Modified $=0.230$. The current state regarding the methods of digital knowledge and skills development and organizational management is at a moderate level in overall, while the desirable state is at a highest level, with PNI Modified $=0.296$. The current state regarding the content of the development toward digital leadership is at a moderate level in overall, while the desirable state is at a highest level, with PNI Modified $=0.270$.

\section{DISCUSSIONS}

Based on the results, the current state is at a moderate level while the desirable state is at a highest level, suggesting the needs for developing digital leadership of school administrator. This is because digital technologies are useful for school management in several areas including instructional management and importantly to allow students to properly and worthily learn about technologies that will benefit the entire educational system to develop and keep pace with competitions. According to Jacob Davidson (2020), as we move further into 2020, well over 4 billion people are now using the Internet - which represents a whopping $53.6 \%$ of the global population, according to recent data from the International Telecommunication Union. Since just after the turn of the century, the number of Internet users has more than quadrupled from just over 1 billion people in 2005, signaling that the world is far more interconnected than ever before. This is also leading to a marked rise in trends that are shaping the future of work (like working from home and telecommuting). In addition, technological change can be utilized to benefit educational management. Joanna Hughes (2019) in an article on six emerging technologies impacting business schools pointed out that technology is shaking up every sector, including both business and higher education. How can we expect to see technology showing up in business school classrooms in the future? The six emerging technologies business school leaders should know about are 1) Recruitment technologies; 2) Classroom Role Playing, Simulations and Gamification; 3) Real-time video classrooms; 4) Robot teachers; 5) Virtual technology; and 6) 5G. As technologies change, school administrators are required to have knowledge and competencies to manage and use them on their own including the management that allows the organization to worthily use technologies. The present results show that the current state of content is at a moderate level, while the desirable state is at a highest level, suggesting the need to expedite leadership development to equip school administrators with the knowledge and competencies to catch up with technologies. Danielle Kost (2020) mentioned about the 6 ways that emerging technology is disrupting business strategy which include 1) Talent and data are more critical than ever.; 2) Technology is propelling business transformation.; 3) Algorithms are changing the pricing game.; 4) Platforms are upending traditional business models.; 5) Companies can test everything.; and 6) Cloud computing is lowering barriers to entry.

In conclusion, the use of school development model towards leadership in digital era affects directly and indirectly the educational management that can keep pace with technological changes. The model includes contents, methods, and goals for development and provides confidence and inspiration for the transformation to take place more systematically and efficiently. 


\section{REFERENCES}

[1] Jirapong Popan. (2019). The Impact of Technological Change. Retrieved 25 January 2020 from https://kru-it.com/design-andtechnology-m2/impact-of-technologychanges/

[2] Chaiyon Paopan. (2016). Concepts and Theories for Being Leaders of School Administrators in the 21st Century. Kalasin Rajabhat University. Retrieved 17 April 2020 from https://so02.tcithaijo.orgcreativity, innovation and entrepreneurship.

[3] Thinking Skills and Creativity, vol. 16, pp. 27-39. (2015), Retrieved from https://doi.org/10.1016/j.tsc.2014.11.006.

[4] Digital Economy and Society. Ministry. (2016). About the Ministry of Digital Economy and Society. Retrieved 14 April 2020 from http://www.mict.go.th.

[5] Information and Communication Technology. Ministry. (2016). Digital Economy and Society Development Plan. 1st Ed. Bangkok: Ministry of Information and Communication Technology. Trilling, B., \& Fadel, C., "21st Century Skills: Learning for Life in Our Times", San Francisco, CA: John Wiley \& Sons, 2009.

[6] Nongluck Sookvanichsilp. (2020). Knowing Favipiravir, an Anti-Covid-19 Drug. Retrieved 8 May 2020 from www.bangkokbiznews.com

[7] Chickering A.W. and Reisser, L., "Education and Identity, 2nd Edition, San Francisco", CA: Jossey-Bass, 1993.

[8] Pakorn Leesakul. (2018). Leadership in Digital Era. Retrieved 6 November 2020 from https://today.line. me/th/pc/article/Leadership+in+Digital+Era

[9] Office of the National Economic and Social Development Board. (2015). The 12th National Economic and Social Development Plan (B.E. 2560-2564). Bangkok: Office of the National Economic and Social Development Board.

[10] Geo-Informatics and Space Technology Development Agency (Public Organization) (2019). Role of GIS in Disaster Management.
Retrieved 20 May 2020 from www.gistda.or.th

[11] Arinya Thalerngsri. SEAC (Southeast Asia Center). Work from Home. (2020). Retrieved May 2020 from https://www.bangkokbiznews.com

[12] D. Scott DeRue and Christopher G. Myers. (2013). Leadership Development: A Review and Agenda for Future Research.[Online]. Retrieved May 20, 2020 from https://www.oxfordhandbooks.com

[13] Digital Leadership“DQ": Mindset + Knowledge + Agility. [Online]. Retrieved June 15, 2020. from

[14] Educational Technology Standards for Administrators (NETS-A). (2010). [Online]. Retrieved June 10, 2020 from https://www.mcrel.org/educational-technology standards-for-administrators-netsa/

[15] Nick Petri. (2011). Future Trends in Leadership Development. [Online]. Retrieved August 9, 2020 from https://law.scu.edu/wpcontent/uploads/ leadership/Future-Trends-inLeadership-

[16] Development.pdf

[17] G.N. Wikramanayake. (2005). Impact of Digital Technology on Education August 2005 Conference: 24th National Information Technology Conference https://www.researchgate.net/publication/216 361364_Impact_of_Digital_Technology_on_ Education

[18] Naniadou, K., \& Claro, M., (2009). 21st Century Skills and Competences for New Millennium Learners in OECD Countries. OECD Education Working Papers, No. 41, OECD Publishing. http://repositorio.minedu.gob.pe/handle/1234 56789/2529

[19] Jacob Davidson. (2020) Here's How Many Internet Users There Are (in 2020) https://money.com/internet-users-worldwide/

[20] Joanna Hughes. (2019). Six Emerging Technologies Impacting Business Schools https://www.keystoneacademic.com/news/six -emerging-technologies-impacting-businessschools 
[21] Danielle Kost. (2020). 6 Ways That Emerging Technology is Disrupting Business Strategy https://hbswk.hbs.edu/item/6-waysthat-digital-technology-disrupts-businessstrategy 